International Journal of Social Science and Economic Research

ISSN: $2455-8834$

Volume: 05, Issue: 03 "March 2020"

\title{
ACCESSING THE IMPACT OF NGOS PROVIDING LEGAL SUPPORT TO WOMEN IN URBAN INDIA
}

\author{
Diya Shukla \\ United World College of South East Asia \\ DOI: 10.46609/IJSSER.2020.v05i03.022 URL: https://doi.org/10.46609/IJSSER.2020.v05i03.022
}

\begin{abstract}
The Constitution and Supreme Court of India guarantee women equal legal rights as men. However, the actualization of these rights has been very limited due to the presence of patriarchal beliefs that have plagued legal structures. This has resulted in the perpetuation of oppression and violence against women to create a system that often safeguards perpetrators and harasses victims in cases of gendered crimes such as sexual assault and domestic violence. This paper has analyzed the causes of sexual and physical violence against women through a legal lens with a conclusion that it is imperative to sensitize and reform legal structures according to the needs of women, to make them more accessible. This paper has explored the role played by Non-Governmental Agencies in providing legal support to women in Urban India by being the integral link between conducive legal recourse and women who are victims as well as providing them with a support system that extends to mental healthcare. Despite the abundance of NGOs in India, their impact has been limited. This paper suggests recommendations to increase the efficacy of these NGOs through centralized networking, improved marketing, and productive interactions with local governments and the media.
\end{abstract}

Keywords: NGOs, Urban India, Women, Indian Society, Rights, Government

\section{INTRODUCTION}

The Indian Society is going through significant transformations that could potentially redefine relationships between various members of communities concerning the roles that they play, the positions of power that they occupy and the inherent expectations that members of the community have from each other. However, even the most urban pockets of India continue to be conservative, which implies that the majority of the Indian population continues to abide by traditional norms that establish gender roles in such a way that they promote the subordination 


\section{International Journal of Social Science and Economic Research}

ISSN: $2455-8834$

Volume: 05, Issue: 03 "March 2020"

and subjugation of women. The participation of women in the workforce in urban India is steadily increasing (Mennon, et. al., 2019). However, women in India are expected to fulfill their responsibilities as 'homemakers' along with pursuing their careers, a burden which is not put on Indian men. Thus the discourse surrounding women's empowerment in India takes into account the diverse problems faced by India women according to their background and experiences.

India is considered to be one of the most unsafe countries for women (Reuters, 2018). The problems that women face stem from their rejection of oppressive social norms which deny women basic human rights such as the Right to Choose. Violence and crimes against women are also seen as a reaction to social progression and social change. Rape and sexual harassment continue to be the biggest challenge that India faces in the 21st century (Kumar, 2003). Women are also denied land $\&$ and property rights guaranteed to them by the constitution. Demands for dowry further perpetuate oppression against women (UPI, 1997). India is also infamous for its gender ratio, which is dramatically skewed in favor of men due to female infanticide and genderselective abortions (Menon-Sen \& Kumar, 2001).

Most of these concerns stem from traditional patriarchal beliefs, thoughts, and practices. However, in a space where women face crimes and oppression that deny them from exercising opportunities to actualize their potential, they should be considered an important and vulnerable stakeholder by the state machinery and legal mechanisms. Women have to cross significant barriers to access justice against crimes that they have been victims of. The Indian Legal system has been a by-product of the one left in India by the British colonizers. Even though laws in India constantly evolve, things such as marital rape are still not criminalized, which goes ahead and shows the influence of patriarchal principles on the law. Most importantly, people working in mechanisms that have been established to ensure justice, the police for instance, also perpetuate oppression against women, one of the most vulnerable stakeholders in Indian society. There have been many instances of victims of rape being harassed by the police which goes on to show how inaccessible justice is to women (Khazan \& Lakshmi, 2012).

In a country where oppression of women in structural and institutionalized, there is a need for organizations that give women the avenue to productively engage with legal systems in the country. Non-governmental organizations - commonly referred to as NGOs, are usually organizations that work independently of governments. Unlike businesses, they do not have a profit-motive but are usually active in humanitarian or social areas. Non Governmental Organizations take up important social issues, ranging from women's empowerment to children's rights and environmental conservation. They are considered to be independent of narratives and practices which influence the actions of state officials against those who are oppressed. Thus, NGOs are considered to be a more conducive space for those who have been 


\section{International Journal of Social Science and Economic Research}

ISSN: $2455-8834$

Volume: 05, Issue: 03 "March 2020"

unfairly treated by the state. There has been a significant growth of Non-Governmental Organizations in India since independence despite continuing to suffer from problems that diminish their impact (Samaj, 2009). However, their potential in terms of causing social change and protecting oppressed minorities is immense, which makes their presence imperative in countries like India.

\section{BACKGROUND}

Religions including Hinduism, Sikhism, and Buddhism have dominated social and economic discourse in India for centuries. Community Service is considered to be a path to God by all indigenous religions of India, which is why it has a long history of civil society based on the concepts of daana (giving) and Seva (service). Voluntary organizations that are voluntary in spirit and seek social justice and welfare instead of profit have been active in the cultural promotion, education, health, and natural disaster relief since the medieval era (Samaj, 2009). Voluntary organizations aiming to promote welfare became more abundant because of the introduction of Christianity, as missionary movements including the Society of Jesus that pioneered development in fields such as education spread to India. They were not influenced by traditional Indian practices like the caste system, which enabled them to work for the emancipation of oppressed castes and women. During the second half of the 19th century, nationalist consciousness spread across India and self-help emerged as the primary focus of sociopolitical movements (Mohanty \& Kumar, 2009). Prominent freedom fighters including Gandhi preached the idea of community service and 'trusteeship' as a principle of independence and self-sustenance. This influenced profit-making corporations to undertake initiatives aimed at social reform and welfare (Chakrabarty, 2017). Furthermore, legislations have been passed since India's independence, that not only legally recognizes Non-Governmental Organizations, but also gives them incentives such as tax cuts to incentivize their promotion (Ministry of Corporate Affairs, 2014). Fueled by these causes, more than 1.5 million NGOs are presently registered in India, working at the local, regional, national and international levels (Samaj, 2009).

As early as in 1951, the Supreme Court of India ruled that a trial is not considered fair if the accused party is disabled from accessing justice. Since then, the Supreme Court has held that fair and equal access to the justice system is imperative for trials to be legitimate (United Nations Development Programme, 2012). These rulings have been inspired by the cognizance of gender, caste and class inequalities in India that have existed in the country for centuries. The Constitution of India obligates the State to ensure access to justice for all people through a variety of means including legal aid which makes it an inalienable, integral and primordial part of the basic structure of the Indian Constitution and a statutory right (United Nations 


\section{International Journal of Social Science and Economic Research}

ISSN: $2455-8834$

Volume: 05, Issue: 03 "March 2020"

Development Programme, 2012). However, it is argued that this right exists only on paper, and it has not yet become a reality for the most vulnerable and marginalized sections of society.

Historically, the legal rights of women in India have been a by-product of religious customs and codes. Even though Hinduism, granted women legal rights, a male guardian was considered to be imperative for women to actualize and access them (Smith, 2008). Moreover, the Hindu code has been extremely fluid and has been interpreted in different ways by different communities. In such a space, judgment and interpretation of the code were executed by local councils. Thus, rights to women as individuals were an unfamiliar concept in the pre-colonial era and practices such as Sati, which coerced women to take their lives after the death of their husbands, continued to be prevalent. Advancements were made over the 19th and 20th centuries as the British outlawed practices like Sati and Child Marriage and women were granted equal political, social and legal rights under the constitution of Independent India (Smith, 2008). However, the presence of traditional patriarchal norms, which are pervasive in all religions practiced in India has continued to prevent the actualization of these rights.

The feminist movement in India dates back to the 19th century with the advocation of formal education for girls, which was absent at the time by Savitribai Phule. Since the past two centuries, legal and political rights have been secured through legislation and systemic reforms. However, patriarchal social conditioning impacts the behavior of individuals responsible to enforce these rights. The denial of justice to women and the restricted access to the legal systems are products of the mindsets of individuals occupying positions of power in recourse mechanisms.

\section{DISCUSSION}

The justice system of India suffers from acute structural problems. The police, for instance, lacks resources to check crimes for a population as large as that of India. More importantly, the police are overwhelmingly dominated by men. Only $7 \%$ of police officers are women, most of whom are kept away from patrol duties and crime investigation. This most negatively impacts investigations of crimes related to gender because of the lack of a female presence and perspective. Studies have also found that women are reluctant to report cases of rape and sexual assault to male police officers due to the fear of inaction, harassment, and stigmatization (Khazan \& Lakshmi, 2012). District and Sessions courts in India, that are responsible for handling criminal procedures are also understaffed. There are only 15 judges in India for a million people which results in the legal system operating sluggishly (Khazan \& Lakshmi, 2012). NonGovernmental bodies working in this sphere are instrumental in being the link between women and legal systems. Women from backward castes face more severe oppression due because of 


\section{International Journal of Social Science and Economic Research}

ISSN: $2455-8834$

Volume: 05, Issue: 03 "March 2020"

their caste and gender identities. NGOs that work with these communities make legal services to them including attorneys, raise awareness about legal and property rights, keep law enforcement agencies in check through instruments such as Right to Information inquiries and also provide other services such as therapy.

There is an abundance of Non-Governmental Organizations in India. 1 NGO exists for every 0.2 million people in India. However, these organizations suffer from certain problems that adversely affect their potential to cause positive social change and promote targeted welfare activities. Moreover, those organizations that work in the sphere of women empowerment face additional structural and social barriers in traditional settings of India. The scarcity of capital and the lack of availability of resources restrict the quantity and quality initiatives and campaigns launched by NGOs. Most organizations run on donations and sponsorships, and those working at the lowest spectrum of society face additional barriers in accessing them due to the absence of a central network and poor marketing. In the form of pro-bono work, law firms often work in partnership with NGOs that provide legal aid to women. Such partnerships must be made judiciously to ensure that the quality of legal work is not compromised by other vested interests of Law Firms that might conflict with the best interests of aggrieved women. Members of political parties in India often possess enough social and legal capital which allows them to perpetrate crimes against women without having the fear of repercussions. Finding ideologically congruent partners in the form of individuals and companies that do not succumb to political pressure is imperative for the functioning of NGOs that provide legal aid to women (Kumaran, 2014). Even though the quantity of NGOs in India is enough to help women across the country actualize their legal rights, the quality of these organizations has always been a cause for concern. The lack of access to resources, legal expertise, networking, and marketing reduces the effectiveness of these organizations severely. Solving these structural problems is considered to be imperative to help NGOs actualize their potential (Kumaran, 2014).

Most importantly, however, organizations working in the sphere of women's empowerment and legal rights of women have to face opposition from religious, political and social groups that oppose the very concept of equality between men and women. The very fact that they enjoy the political and social capital in India to occupy positions of apparent or actual power deters the impact of any movement or organization working to help women actualize their rights. Not only do they engage in victim-blaming in cases of domestic violence and sexual assault, the violence, and intimidation perpetrated by them hamper the day to day functioning of NGOs. The rise of the right-wing in India has enabled orthodox groups to intimidate NGO workers and lawyers through instruments including death threats and to prevent women from attending awareness campaigns about their legal rights (Vij, 2019). 


\section{International Journal of Social Science and Economic Research}

ISSN: $2455-8834$

Volume: 05, Issue: 03 "March 2020"

\section{CONCLUSION}

The inability of women in India to access legal recourse, especially those who belong to backward classes and castes, due to the presence of structural barriers fueled by social conditioning leads to the perpetuation of oppression and marginalization. The lack of efficient legal recourse mechanisms has contributed to the increase in physical and sexual violence against women and the denial of economic capital through alienating women from their land and property rights as well as alimony, in cases of abandonment, which are also common in India. Changes within legal and state structures in unfeasible in the short term, given they are controlled by people who influenced by or are a part of orthodox religious and social groups like the Rashtriya Swayamsevak Samaj that have been fundamentally opposed to the equality of men and women. In such a space Non-Governmental Organizations, which thrive on the principles of collectivization and inclusivity, are the only modality through which women can actualize their legal rights in India. However, despite their abundance of NGOs, their impact has been limited and has not trickled down to the most marginalized sections of society.

There is a need for NGOs to start working in collaboration with state agencies and governments. Women's rights groups have been instrumental in various Parliamentary Acts that protect and promote women's constitutional and legal rights including The Dowry Prohibition Act of 1961, establishing the National Commission for Women and actualizing reservations for women in local and village level elections. Moreover, engaging with governments also allows NGOs to change structures from within and induce sensitivity in legal structures and proceedings. Pressure from NGOs has forced reforms in the police system in many cities, including Mumbai and Delhi. Non-government Organisations that run awareness campaigns to address women's legal rights issues should develop active collaborative partnerships with traditional mass media and online media to increase outreach. Engagement with the public is important not only because it increases the access to private resources but also because it mobilizes people in a democracy for a social cause. In this case, mobilization exerts pressure on political parties and state officials to make procedures more sensitive and conducive to the needs of women. Organizations including 'Majlis Manch', 'Guria India', and 'Prerana' have successfully implemented procedures that help marginalized women in urban India access legal mechanisms by partnering with attorneys and supplementing the efforts of law enforcement agencies (Devyani, 2019). They also make therapy accessible to women to help them recover from the trauma of abuse. However, most of these initiatives are localized which limits access. To cater to the most vulnerable and marginalized stakeholders, there is a need to establish a pan-national network of organizations that provide legal aid to women in India. 
International Journal of Social Science and Economic Research

ISSN: $2455-8834$

Volume: 05, Issue: 03 "March 2020"

The prosperity of a country does not only dependent on markers like economic development but also the emancipation of historically oppressed minorities. Fueled by migration, the urban population of India consists of identities that suffer through oppression at multiple levels due to intersectionality. The influence of orthodox social forces, which are responsible for the identitybased oppression in the first place, often influences state structures and legal systems, making them inaccessible to the marginalized. In such a space, Non-Governmental Organizations become the vital link that helps women in urban India access legal recourse and mental healthcare, by bridging economic, social and cultural gaps. However, to maximize potential and actualize change in a population as large and diverse as India, NGOs working for the legal rights of women need to affect changes in their structure and working, to improve their efficiency and effectiveness.

\section{BIBLIOGRAPHY}

Chakrabarty, B. (2017). Gandhi's Doctrine of Trusteeship: Spiritualizing Interpersonal Relationship. Accessed on 2nd 2019 http://ncds.nic.in/sites/default/files/WorkingandOccasionalPapers/WP67NCDS.pdf

Devyani, R. 10 NGOs helping women to fight for their rights in India. Give India, 21st September 2019

Khazan, O., Lakshi, R. 10 reasons why India has a sexual violence problem. The Washington Post, 29th December 2012 https://www.washingtonpost.com/news/worldviews/wp/2012/12/29/india-rape-victimdies-sexual-violence-proble/

Kumar, R. (1993). The agitation against rape. Accessed on 1st November, 2019

Kumaran, M. (2014). Roles, Responsibilities and Trends of NGOs in Women Empowerment. Indian Journal of Public Administration, Accessed on 3rd November 2019 http://www.iipa.org.in/New\%20Folder/17--Muthusami.pdf

Menon, S., Tomy, D., Kumar, A. (2019). Female Work and Labor Force Participation in India: A Meta Study. United Nations Development Program. Accessed on 1st November 2019 https://www.sattva.co.in/wp-content/uploads/2019/06/Sattva UNDP Female-Work-AndLabour-Force-Participation-In-India.pdf

Menon-Sen, K.; Kumar, A.K.S. (2001). Women in India: How Free? How Equal?.United Nations. Accessed on 1st November 2019 
International Journal of Social Science and Economic Research

ISSN: $2455-8834$

Volume: 05, Issue: 03 "March 2020"

Ministry of Corporate Affairs. (2014). Companies Regulations: 1956. Accessed on 2nd November 2019 http://www.mca.gov.in/Ministry/actsbills/rules/CR1956.pdf

Mohanty, M., \& Singh,A.K. (2001). Voluntarism and Government - Policy, Programme and Assistance. VANI, Accessed on 2nd November 2019

Reuters. (2018). Press Release:The world's most dangerous countries for women 2018 by Thomson Reuters Foundation. Thomas Reuters Foundation, Accessed on 1st November 2019

Samaj, P. (2009). Overview of Civil Society Organizations in India. Asian Development Bank, Accessed on 1st November https://www.washingtonpost.com/news/worldviews/wp/2012/12/29/india-rape-victimdies-sexual-violence-proble/

Smith, B.G. (2008). The Oxford Encyclopedia of Women in World History: Oxford University Press, Accessed on 2nd November 2019

United Nations Development Programme. (2012). International Conference on Equitable Access to Justice: Legal Aid and Legal Empowerment. Accessed on 2nd November 2019 https://www.undp.org/content/dam/india/docs/DG/equitable-access-to-justice-legalempowerment-legal-aid-and-making-it-work-for-the-poor-and-marginalised.pdf

United Press International (1997). Kitchen fires kill Indian brides with inadequate dowry. Accessed on 1st November 2019

Vij, S. India's ruling Bharatiya Janata Party has a rape problem. Quartz India, 25th September 2019 https://qz.com/india/1715615/kathua-unnao-up-cases-show-modis-bjp-has-a-rapeproblem/ 